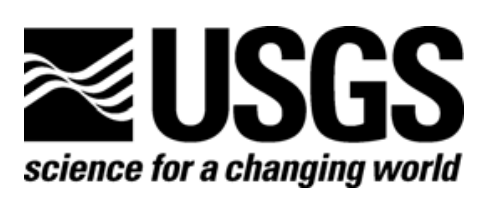

\title{
Regional Geochemical Results from the Analyses of Rock, Soil, and Vegetation Samples-Big Delta B-2 Quadrangle, Alaska
}

By L.P. Gough, W.C. Day, J.G. Crock, B.M. Gamble, M.W. Henning, C.M. Ager, A.L. Meier, P.H. Briggs, Z.A. Brown, and M. Adams

Open-File Report 2005-1431

U.S. Department of the Interior U.S. Geological Survey 


\section{U.S. Department of the Interior \\ Gale A. Norton, Secretary}

\section{U.S. Geological Survey \\ P. Patrick Leahy, Acting Director}

U.S. Geological Survey, Reston, Virginia 2005

Revised and reprinted: 2005

For product and ordering information:

World Wide Web: http://www.usgs.gov/pubprod

Telephone: 1-888-ASK-USGS

For more information on the USGS - the Federal source for science about the Earth,

its natural and living resources, natural hazards, and the environment:

World Wide Web: http://www.usgs.gov

Telephone: 1-888-ASK-USGS

Suggested citation:

Gough, L.P., Day, W.C., Crock, J.G., Gamble, B.M., Henning, M.W., Ager, C.M., Meier, A.L., Briggs, P.H., Brown, Z.A., and Adams, M., 2005, Regional geochemical results from the analyses of rock, soil, and vegetation samples--Big Delta B-2 quadrangle, Alaska: U.S. Geological Survey Open-File Report 2005-1431, 13 p. plus tables; URL: http://pubs.usgs.gov/of/2005/1431/.

Any use of trade, product, or firm names is for descriptive purposes only and does not imply endorsement by the U.S. Government.

Although this report is in the public domain, permission must be secured from the individual copyright owners to reproduce any copyrighted material contained within this report. 


\section{Contents}

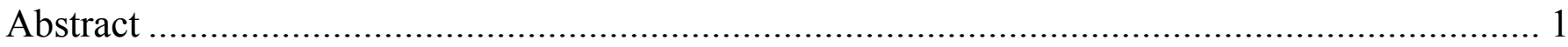

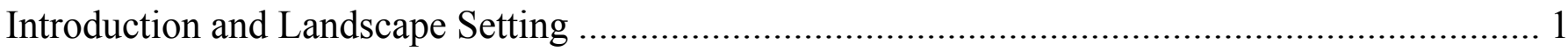

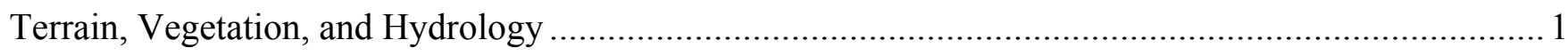

Geology

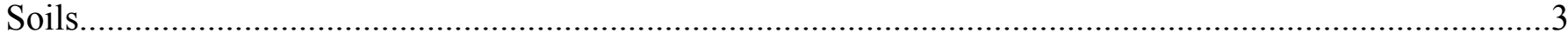

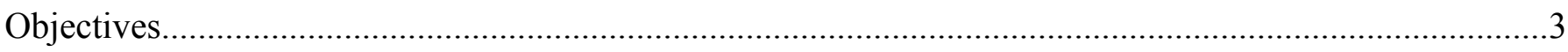

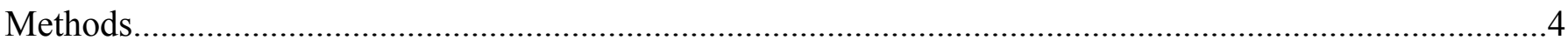

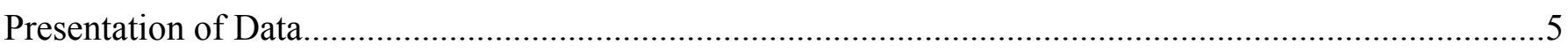

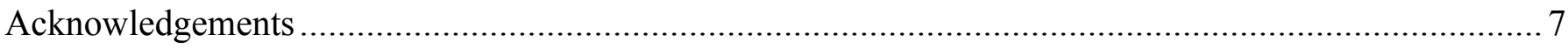

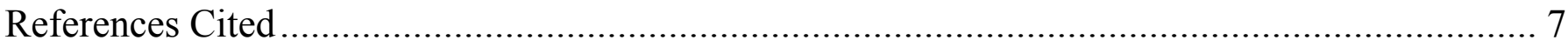

\section{Figures}

1. Location of the Big Delta B-2 quadrangle in east-central Alaska, showing its position relative to the Tintina and Denali Faults and the cities of Delta Junction and Fairbanks. 9

2. Labeled rock, rock core, and quartz vein sampling sites in the Big Delta B-2 quadrangle, Alaska superimposed on the regional hydrology. For precise site coordinates refer to tables 3, 4, and 5. Modified after Day and others (2003)....

3. Labeled vegetation and soil sampling sites in the Big Delta B-2 quadrangle, Alaska superimposed on the regional hydrology. For precise site coordinates refer to table $2 \ldots . . .11$

4. Generalized geologic map of the Big Delta B-2 quadrangle, Alaska with vegetation and soil sampling locations. Modified after Day and others (2003)....

\section{Tables (see separate online Excel file)}

1. Analytical methodology for rocks, soils, soil water, and plant samples. The methods follow those outlined in Crock and others (1999) and Taggart (2002). 
2. Sample site names, coordinates, and geology for plant, soil, and soil water sampling sites.

3. Chemical analysis results for the concentration of major oxides, trace and rare earth elements, and gold in rock samples.

4. Chemical analysis results for the concentration of trace and rare earth elements and gold in rock samples elements from select drill core from the Pogo gold deposit.

5. Chemical analysis results for the concentration of major oxides, trace and rare earth elements, and gold in quartz vein samples.

6. Chemical analysis results for the concentration of elements in A-, B-, and C-horizon soils.

7. Chemical analysis results for the concentration of elements in distilled water soil leachates.

8. Chemical analysis results for the concentration of elements in grayleaf willow leaf material.

9. Chemical analysis results for the concentration of elements in grayleaf willow twig material.

10. Chemical analysis results for the concentration of elements in green alder leaf material.

11. Chemical analysis results for the concentration of elements in green alder twig material.

12. Chemical analysis results for the concentration of elements in feather moss whole plant material. 


\title{
Regional Geochemical Results from the Analyses of Rock, Soil, and Vegetation Samples-Big Delta B-2 Quadrangle, Alaska
}

By L.P. Gough, W.C. Day, J.G. Crock, B.M. Gamble, M.W. Henning, C.M. Ager, A.L. Meier, P.H. Briggs, Z.A. Brown, and M. Adams

\begin{abstract}
We report the chemical analyses for rocks, soil, soil water, and vegetation, collected from throughout the Big Delta B-2 quadrangle in east-central Alaska, for the period 1998-2002. This study focused on the integration of geology and bedrock geochemistry with the geochemistry and biogeochemistry of soil and vegetation. The study objectives were the characterization of the regional tectonic setting, creation of a quadrangle geologic map, understanding the effect of bedrock geology on the geochemical landscape signatures, and the establishment of estimations of predevelopment geochemical baseline concentrations for a variety of matrices. The impetus for this work was the discovery in 1996 of the Pogo lode gold deposit in the northwest corner of the quadrangle, the subsequent increase in mineral exploration, and the overall mineral-occurrence importance to the State and of the Yukon-Tanana Upland (Internal Highlands Ecoregion). Geochemical data for the various rock units, soil horizons, grayleaf willow, green alder, feather moss, and soil-water extracts are given along with the analytical methodology used. The data are being released at this time with minimal interpretation.
\end{abstract}

\section{Introduction and Landscape Setting}

\section{Terrain, Vegetation, and Hydrology}

The Big Delta B-2 quadrangle is located in the Yukon-Tanana Upland (Interior Highlands Ecoregion, Gallant and others, 1995) in east-central Alaska about $48 \mathrm{~km}$ northeast of the town of Delta Junction, Alaska (fig. 1). The area is part of the "Tintina gold province", a 200-km-wide, 1,200-km-long arc, bounded by the Tintina-Kaltag fault systems on the north and the DenaliFairwell fault systems on the south. This region extends from northern British Columbia westward through east-central Alaska to southwest Alaska (Smith, 2000; Hart and others, 2002). The province includes such large gold deposits as Pogo, Fort Knox, True North, Donlin Creek, and Shotgun and remains a prime area for gold exploration.

The Pogo Mine projects that it will begin extracting gold on site in early 2006. Its discovery in 1996 caused a flurry of exploration activity in the Yukon-Tanana Upland, especially in the B-2 quadrangle, and prompted the need for detailed geologic mapping, and predevelopment geochemical baseline studies. The Pogo deposit discovery also created renewed interest in 
understanding the tectonic setting and metallogeny of the Upland and of the Pogo-type gold deposit (high-grade, sulfide-bearing, quartz-vein deposit; Smith and others, 2000).

The Big Delta B-2 quadrangle is characterized by vegetated, rounded, low mountains with scattered sparsely vegetated to barren high peaks (the highest point, Shawnee Peak, at 1,433 m). The Goodpaster River, the area's largest stream, drains in an arc from the northeast corner of the quadrangle to the southwest corner. The Goodpaster River drainage is characterized as broad and meandering. Central Creek, its major tributary in the study area, runs east to west across the quadrangle and its drainage is narrower and has a steeper gradient. The boreal forest vegetation of the region is composed of closed spruce-hardwood subarctic forest containing white and black spruce, paper birch, aspen, and balsam poplar. The alpine tundra (tree line is at about $900 \mathrm{~m}$ ) is composed of low shrubs (willow, birch, spirea, high bush cranberry) and a ground cover of forbs, mosses, and lichens. Fires are common due mainly to lightning strikes, and most of our study sites in forested areas showed evidence of past fire disturbance. The area has an interior Alaska continental climate characterized by warm, dry summers, very cold, dry winters, a day-length that varies from about 4.5 hours in December to 19.5 hours in June, and broad fluctuations in ambient temperature.

\section{Geology}

Crystalline rocks of the Yukon-Tanana Upland of east-central Alaska underlie the study area. Weber and others (1978) provided an excellent regional geologic map of the Big Delta $1: 250,000$ quadrangle. Day and others (2003) published the geologic map that accompanies this geochemical data report. The oldest geologic units within the map area are a metasedimentary series of biotite-sillimanite gneiss, quartzofeldspathic biotite gneiss, and a sequence of metagraywacke locally interlayered with quartzite and metapelite. The protoliths for these metasedimentary units included epiclastic to pelitic sediments. U-Pb age dating of zircons from these units indicate they have Proterozoic cores (Day and others, 2003) and are thought to have been shed from the margin of the North American continental craton.

The region experienced two major episodes of plutonism, one during the Devonian $(\sim 365$ $\mathrm{Ma})$ and another during the Cretaceous ( 104-113 Ma). The Devonian plutonic rocks include augen gneiss (Dusel-Bacon and Aleinikoff, 1985), dioritic orthogneiss, and granodioritic orthogneiss (Day and others, 2003). These intrusive phases experienced deformation during at the latest during the regional Cretaceous tectonic event. Mafic gneisses, whose protoliths were probably basaltic, and serpentinized ultramafic schists, which had a peridotitic protoliths, were structurally interleaved with the metasedimentary units as well as thrust upon the Devonian augen gneisses. The age of thrusting of these mafic to ultramafic units is not fully constrained, but could have been during the pervasive Cretaceous ( $\sim 114-116 \mathrm{Ma})$ regional deformation.

Cretaceous plutons intruded the region between about 104 to $113 \mathrm{Ma}$, after the regional tectonism that produced the penetrative ductile deformational fabric. The intrusive rocks include the Shawnee Peak intrusion, dioritic units within the Pogo mine area, the Goodpaster granite, the granite of Swede Peak, granodioritic dikes, and various granodioritic to granite stocks. Tertiary $(\sim 50$ ? Ma) basaltic dikes represent the last known igneous activity in the region.

Gold mineralization, such as that of the Pogo deposit, was spatially and temporally associated with various phases of the Cretaceous plutonic rocks. The gold primarily occurs in 
quartz veins bearing arsenopyrite, pyrite, and various other accessory sulfide minerals (Smith and others, 2000). See Wilson and others (1985), Dusel-Bacon and Hansen (1992), Smith and others (2000), Dusel-Bacon and others (2002), Dillworth and others (2002), Selby and others (2002), and Day and others (2003) for a more thorough discussion on the geologic setting, deformational history, and age of gold mineralization for the area.

\section{Soils}

Soils at our study sites are classified as Cryepts (Inceptisols), Orthels (Gelisols), and a few Spodosols (possessing a distinctive Fe hardpan layer). Greater than 50 percent of our sites were near saturation at the time of collection and permafrost, when present, was commonly observed from 15 to $50 \mathrm{~cm}$ below the surface. Most sites had silty-loam to fine-sandy-loam A soil horizons with abundant root penetration. The A horizon was usually $<10 \mathrm{~cm}$ in thickness and dark brown in color and a few possessed an ash-colored eluviation (E) horizon. The B horizon was usually about as thick as the A horizon, lighter and more reddish in color, and contained moderate root volume. C soil horizons commonly extended below 20 to $40 \mathrm{~cm}$ in depth, and consisted of fine to coarse sand with small blocks of angular bedrock and few roots. The presence of silt (aeolian loess) in the soil horizons was universal and plays an important role in the definition of soil geochemical signatures. Although it is possible that some of the soils developed from alluvium, most sites were intentionally located well above contemporary flood levels on slopes that did not exceed 15 percent. Geomorphic signs of down-slope soil movement (solifluction lobes and outwash fans), however, indicate that the upper horizons of many of these soils were mostly colluvial in origin. An effort was always made to collect mature, residual soils whenever possible. If colluvium predominated, then we attempted to locate the soil pit in an area where the soil was derived from a single rock unit. Cryoturbation, most commonly signaled by the presence of hummocks, was observed only on a very few of our sites where the forest was sparse and permafrost was shallow.

\section{Objectives}

The objectives of U.S. Geological Survey (USGS) studies in the Big Delta B-2 quadrangle include: (1) characterization of the tectonic setting, petrogenesis, and metallogeny of plutonic rocks of the Yukon-Tanana Upland by identifying and understanding dominant structural features in key areas, (2) geological mapping in support of hydrogeochemical, geochemical, and biogeochemical studies, (3) definition of geochemical signatures imparted to the aqueous, soil, and biogeochemical environments from the geologic (mineralized and non-mineralized) substrate, and (4) establishment of pre-development geochemical baselines for soils and vegetation in selected watersheds. This latter objective has the additional goal of providing information on the extent of rock-water interactions and element bioavailability in different geologic terrains.

One aspect of these studies was the collection and geochemical analysis of rock, soil, and vegetation. This report publishes the results of those analyses. Hydrologic, hydrogeochemical, and stream sediment geochemical data will be presented in a separate report. The geology of the Big Delta B-2 quadrangle is published in Day and others (2003). 


\section{Methods}

Samples of rocks, soil, and vegetation were collected between 1998 and 2002 at numerous study sites throughout the B-2 quadrangle. Soils and vegetation tsampling sites can be segregated into three categories: (1) those along Liese Creek that were specifically targeted to elucidate the geochemical and biogeochemical signature of the diorite and tonalite unit (Cretaceous igneous rock unit) that hosts the Pogo deposit; (2) those from prospect trenches that penetrated the mineralized granitoid dikes on Shawnee Mountain; and (3) those broad regional sites from throughout the B-2 quadrangle designed to characterize the influence of the various lithologic units on the geochemical and biogeochemical signature of soils and vegetation. These three sample categories are represented by 6,1 , and 41 sites, respectively.

Bedrock samples were collected from all of the dominant rock units in the B-2 quadrangle. However, bedrock geochemical sampling from the Tech-Cominco Pogo claim block, which was the area south and east of the Goodpaster River north of Central Creek and west of Sonora and Occidental Creek, was limited to a traverse down Liese Creek (samples 99AD012-99AD018 and 99AG001A-99AG009) shown in table 3 and selected drill core intervals (the "POGO-XX" samples) listed in table 4. Though limited, these samples do provide important information on the composition of the major bedrock units in this area. Sampling throughout the remainder of the B-2 quadrangle focused on providing representative geochemistry of the major bedrock units that were collected distal of known mineralization and alteration areas as well as areas within mineralized zones (table 3). Rock samples also include quartz vein material from throughout the area (table 5).

Soil and vegetation study sites were selected on the basis of the following landscape and soil criteria: (1) sites possessed soils (Gelisol, Inceptisol, and (or) Spodosol) developed over a known lithologic unit, (2) sites were low in peat, (3) if permafrost was present, depth to frost layer was $>30 \mathrm{~cm}$, (4) if over Quaternary deposits, sites were composed of colluvium and not alluvium (located above and out of the flood plain), and (5) soils were mature to the point of having recognizable horizonal development. They were also selected on the basis of the following ecosystem and vegetation criteria: (1) sites were either white spruce, mixed hardwood boreal forests or open alpine tundra that had not been recently burned (within the past 30-50 years), and (2) sites were as well drained as possible for the area (usually with a southerly or ridge crest exposure). Commonly the sites were well drained if they lacked permafrost. At least one soil pit was dug at each study site. Where available, samples of A1, B, and C soil horizon material (about $1 \mathrm{~kg}$ ) were collected using a spade, mixed separately using a plastic spatula and bucket, and placed in paper USGS soil sample bags. In the laboratory the soils were mechanically disaggregated, sieved at 10 -mesh $(2 \mathrm{~mm})$, and the $<10$ mesh material was further ground to pass a 100 mesh (150 micrometer) sieve. The ground material was used for all total chemical analyses.

Samples of the terminal 10-15 cm of the stems with leaves of grayleaf willow (Salix glauca L.) and green alder (Alnus crispa (Ait.) Pusch) were clipped with stainless steel shears and placed in $\mathrm{Hubco}^{\mathrm{TM}}$ polypropylene/cotton sample bags. These samples were usually collected in close proximity to the soil collection pit. This material represents a composite of material collected from 1 to 4 individual plants at each site. In the laboratory the material was dried at ambient temperature, ground in a Wiley ${ }^{\mathrm{TM}}$ mill to pass a $2 \mathrm{~mm}$ screen, and an aliquot ashed at $500^{\circ} \mathrm{C}$. In addition, samples of feather moss (Hylocomium splendens (Hedw.) BSG) were collected and placed in Hubco ${ }^{\mathrm{TM}}$ bags. This moss is a robust, densely growing ground moss that is nearly ubiquitous in 
the moist sub-arctic boreal forest understory. In the laboratory the moss material was separated from extraneous organic detritus, rinsed thoroughly in deionized-distilled water, air dried, ground in a Wiley ${ }^{\mathrm{TM}}$ mill to pass a $2 \mathrm{~mm}$ screen, and an aliquot ashed at $500^{\circ} \mathrm{C}$.

Water extracts of soils were performed on the ground -10 mesh $(2 \mathrm{~mm})$ fraction. A 1:5 (sample:water) ratio was used; $5 \mathrm{~g}$ of soil were mixed with $25 \mathrm{~mL}$ of demineralized/deionized nano-pure water in a $50 \mathrm{~mL}$ centrifuge tube. The tube was placed on a reciprocating shaker at about 60 cycles per minute for 2 hours. The mixture was allowed to settle and was centrifuged at about 5,000 rpm for 10 minutes. The $\mathrm{pH}$ and conductivity of the liquid were determined. An aliquot of the liquid was filtered through a 0.45 micrometer syringe filter and this solution was then analyzed for elemental content using inductively coupled plasma-mass spectrometry (ICP-MS) (table 1).

Table 1 lists the laboratory methodologies used for the analysis of rock, soil, soil water, and plant samples. Details of the QA/QC protocols of the Denver laboratories of the U.S. Geological Survey are given in Taggart (2002). These methods incorporate the periodic analysis of blanks, laboratory-made duplicates, and standard USGS and NIST materials.

\section{Presentation of Data}

The data listed in the following tables for rocks, soils, soil water, and vegetation are presented with a minimum of interpretation. This report is intended as a data release at this time and is available both as a written report and digitally on a CD. The discussion that follows describes the contents of these tables.

The following field identification (Field ID) convention was used for the labeling of samples:

(1) Rocks (tables 3-5).

99AD001A. 99, year; $\underline{\mathrm{A}}$, Alaska; $\underline{\mathrm{D}}$, collector (Warren Day) or $\underline{\mathrm{G}}$, collector (Bruce

Gamble); $\underline{001}$, site number; $\underline{A}$, first of more than one sample at this site.

POGO-1. First of 14 drill core samples collected at the Pogo mine.

(2) Soils (table 6).

99AK01A. 99, year; $\underline{\mathrm{AK}}$, Alaska; $\underline{01}$, site number; $\underline{\mathrm{A}}$, horizon. Sometimes the latter was preceded by an " $\underline{\mathrm{S}}$ " which indicates "soil". $\underline{\mathrm{B}}$ and $\underline{\mathrm{C}}$ horizons were also collected.

(3) Soil water (table 7).

99AKA01. 99, year; $\underline{\mathrm{AK}}$, Alaska; $\underline{\mathrm{A}}$, horizon; $\underline{01}$, site number. Sometimes the latter two positions are reversed.

(4) Vegetation (tables 8 and 9).

99AKSGL-01. 99, year; AK, Alaska; SGL, Salix glauca (willow) leaf; -01, site number. $\underline{01 \mathrm{AK} 01 \mathrm{WL}}$. 01, year; $\underline{\mathrm{AK}}$, Alaska; $\underline{01}$, site number; WL, Salix glauca (willow) leaf. 99AKSGT01. 99, year; $\underline{\text { AK }}$, Alaska; SGT, Salix glauca (willow) twig; -01, site number. $\underline{01 \mathrm{AK} 01 \mathrm{WT}}$. $\underline{01}$, year; $\underline{\mathrm{AK}}$, Alaska; $\underline{01}$, site number; $\underline{\mathrm{WT}}$, Salix glauca (willow) twig.

(5) Vegetation (tables 10 and 11)

99AKACL-01. 99, year; $\underline{\mathrm{AK}}$, Alaska; ACL, Alnus crispa (alder) leaf; -01, site number. $\underline{01 \mathrm{AK} 01 \mathrm{AL}}$. 01, year; $\underline{\mathrm{AK}}$, Alaska; 01, site number; $\underline{\mathrm{AL}}$, Alnus crispa (alder) leaf. 99AKACT-01. 99, year; $\underline{\mathrm{AK}}$, Alaska; $\underline{\mathrm{ACT}}$, Alnus crispa (alder) twig; -01, site number. 01AK01AT. 01, year; $\underline{\mathrm{AK}}$, Alaska; 01, site number; $\underline{\mathrm{AT}}$, Alnus crispa (alder) twig. 
(6) Vegetation (table 12).

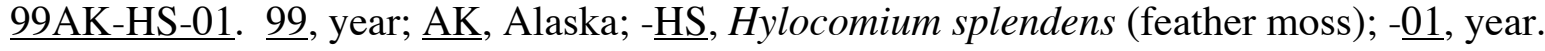

The analytical data for soil samples, all reported on an ash weight basis, are given in table 6 . About 10 percent of the samples were randomly selected in the laboratory for duplicate analysis; these are noted with an " $\mathrm{X}$ " following the field ID number. The four Shawnee Peak pit samples were collected within and near a prospecting trench that had been mechanically dug near granitoid dike outcrop. This material is most like $\mathrm{C}$-horizon soil and is slightly elevated in the concentration As and $\mathrm{Au}$.

Table 7 gives the results of the analysis of soil leachate. A subset of A-, B-, and C-horizon soils, collected in 1999 and 2001, were leached using demineralized/deionized water (see methods section) and the leachate was then analyzed. The purpose of this study was to determine the readily bioavailable element fraction of soil as measured by a leach that simulates rainwater. Most of the data for the individual elements is highly variable and shows major differences among soil horizons as well as among sampling sites and bedrock type.

In 1999, 2001, and 2002, grayleaf willow, and in 1999 and 2002 green alder were collected where they were found adjacent to the pit used for sampling soil. In addition, feather moss was collected at each of the 1999 sites. Following analysis of the 1999 vegetation data, it was decided that the collection of willow would continue but not for alder or moss. This was because preliminary analysis of the data showed willow to be more variable and to possess a biogeochemical signature that was more closely linked to the bedrock geochemistry. A decision was made, therefore, to decrease the analytical burden by sampling mostly willow in the subsequent years. From an ecosystem perspective, willow is an important component of the northern boreal forest because it is heavily utilized for browse by many different animal species and it will bioaccumulate Cd (Gough and others, 2001; 2002).

The willow and alder samples were separated into leaf and twig material prior to analysis and the data are reported separately in tables 8-11. These data are on an ash-weight basis; conversion to a dry-weight basis can be made by dividing the percent ash yield for the sample by 100 and then multiplying this value by the element concentration (as reported in the tables). The resultant value is considered more biologically relevant and is the most common method of interpreting element concentration data in plants.

The 1999 moss samples were collected as part of a Northern Hemisphere coordinated program for the use of feather moss as a biomonitor of atmospheric element deposition (Berg and Steinnes, 1997). Moss was not systematically collected after 1999. This collection is part of a growing body of moss biogeochemical data from Alaska specifically targeted at the understanding of regional airborne metal deposition patterns (see, for example, Crock and others, 1992, and Gough and Crock, 1997).

The analytical detection limits for some methods changed over the length of the study (1998-2002)because of methodology improvements. 


\section{Acknowledgements}

We wish to thank Moira Smith, Jack DiMarchi, and Paul Roberts, Teck-Cominco Ltd., for their logistical support at the Pogo camp, and for sharing their insight into the geology and geochemistry of the Pogo claim block. In addition, Teck-Cominco Ltd. assisted us throughout the study by providing access to helicopter fuel. We thank Jules Tileston, Stanley Foo, and Jim Vohden, Alaska Department of Natural Resources, for contributing to the cost of the helicopter, helping with logistics, and giving their enthusiastic support for the project. Helicopter pilots Leonard Warren and Marty Stauber were especially skilled and helpful. The helibase support given by the Alaska Department of Natural Resources Division of Forestry at Delta Junction is gratefully acknowledged.

\section{References Cited}

Berg. T., and Steinnes, Eliv, 1997, Use of mosses (Hylocomium splendens and Pleurozium schreberi) as biomonitors of atmospheric deposition--from relative to absolute values: Environmental Pollution, v. 98, p. 61-71.

Crock, J.G., Severson, R.C., and Gough, L.P., 1992, Determining baselines and variability of elements in plants and soils near the Kenai National Wildlife Refuge, Alaska: Water, Air, and Soil Pollution, v. 63, p. 253-271.

Crock, J.G., Arbogast, B.F., and Lamothe, P.J., 1999, Laboratory methods for the analysis of environmental samples: in Plumlee, G.S. and Logsdon, M.J. (eds.), Review in Economic Geology Volume 6A, The Environmental Geochemistry of Mineral Deposits, Part A: Processes, Techniques, and Health Issues: Society of Economic Geologists, p. 265-287.

Day, W.C., Aleinikoff, J.N., Roberts, Paul, Smith, Moria, Gamble, B.M., Henning, M.W., Gough, L.P., and Morath, L.C., 2003, Geologic map of the Big Delta B-2 quadrangle, east-central Alaska: U.S. Geological Survey Geologic Investigations Series I-2788, 1:63,360 scale, map with interpretations.

Dillworth, Katherine, Ebert, Shane, Mortensen, J.K., Rombach, Cameron, and Tosdal, R.M., 2002, Reduced granites and gold veins in the Pogo area, east-central Alaska: Geological Society of America, Abstracts with Programs, 2002, v. 34, n. 6, p. 114.

Dusel-Bacon, Cynthia, and Aleinikoff, J.N., 1985, Petrology and tectonic significance of augen gneiss from a belt of Mississippian granitoids in the Yukon-Tanana terrane, east-central Alaska: Geological Society of America Bulletin, v. 96, p. 411-425.

Dusel-Bacon, Cynthia, and Hansen, V.L., 1992, High-pressure amphibolite-facies metamorphism and deformation within the Yukon-Tanana and Taylor Mountain terranes, eastern Alaska, in Bradley, D.C., and Dusel-Bacon, Cynthia, eds., Geological studies in Alaska by the U.S. Geological Survey, 1991: U.S. Geological Survey Bulletin 2041, p. 140-159.

Dusel-Bacon, Cynthia, Lanphere, M.A., Sharp, W.D., Layer, P.W., and Hanson, V.L., 2002, Mesozoic thermal history and timing of structural events for the Yukon-Tanana Upland, eastcentral Alaska $-{ }^{40} \mathrm{Ar} /{ }^{39} \mathrm{Ar}$ data from metamorphic and plutonic rocks: Canadian Journal of Earth Sciences, v. 39, p. 1013-1051.

Gallant, A.L., Binnian, E.F., Omernik, J.M., and Shasby, M.B., 1995, Ecoregions of Alaska: U.S. Geological Survey Professional paper 1567, 73 p. and map.

Gough, L.P., and Crock, J.G., 1997, Distinguishing between natural geologic and anthropogenic trace element sources, Denali National Park and Preserve: in Dumoulin, J.A. and Gray, J.E. (eds.), Geologic Studies in Alaska by the U.S. Geological Survey, 1995: U.S. Geological 
Survey Professional Paper 1574, p. 57-71.

Gough, L.P., Crock, J.G., Day, W.C., and Vohden, J., 2001, Biogeochemistry of arsenic and cadmium, Fortymile River watershed, east-central Alaska, in, Gough, L.P. and Wilson, F.H., eds., Geologic Studies in Alaska by the U.S. Geological Survey: U.S. Geological Survey Professional Paper 1633, p. 109-126.

Gough, L.P., Crock, J.G., and Day, W.C., 2002, Cadmium accumulation in browse vegetation, Alaska-implication for animal health, in Skinner, H.C.W. and Berger, A., eds., Geology and Health-Closing the Gap: Oxford University Press, p. 77-78.

Hart, C.J.R., McCoy, D.T., Goldfarb, R.J., Smith, M., Roberts, P., Hulstein, R., Bakke, A.A., and Bundtzen, T.K., 2002, Geology, exploration, and discovery in the Tintina Gold Province, Alaska and Yukon: Society of Economic Geologists, Special Publication 9, p. 242-274.

Selby, David, Creaser, R.A., Hart, C.J.R., Rombach, C.S., Thompson, J.F.H., Smith, M.T., Bakke, A.A., and Goldfarb, R.J., 2002, Absolute timing of sulfide and gold mineralization-A comparison of Re-Os molybdenite and Ar-Ar mica methods from the Tintina gold belt, Alaska: Geology, v. 30, no. 9, p. 791-794.

Smith, M.T., 2000, The Tintina gold belt: an emerging gold district in Alaska and Yukon: in Tucker, T.L., and Smith, M.T., eds., The Tintina Gold Belt: Concepts, Exploration, and Discoveries: British Columbia-Yukon Chamber of Mines, Cordilleran Round-Up Special Volume 2, p. 1-3.

Smith, M.T., Thompson, J.F.H., Moore, K.H., Bressler, J.R., Layer, Paul, Mortensen, J.K., Abe, I., and Takaoka, H., 2000, The Liese zone, Pogo property: a new high-grade gold deposit in Alaska, in Tucker, T.L., and Smith, M.T., eds., The Tintina Gold Belt: Concepts, Exploration, and Discoveries: British Columbia-Yukon Chamber of Mines, Cordilleran Round-Up Special Volume 2, p. 131-144.

Taggart, J.E., ed., 2002: Analytical methods for chemical analysis of geologic and other materials, U.S. Geological Survey: U.S. Geological Survey Open-File Report 02-223, pages not numbered consecutively. (http://pubs.usgs.gov/of/2002/ofr-02-0223/)

Weber, F.R., Foster, H.L., Keith, T.E.C., and Dusel-Bacon, Cynthia, 1978, Preliminary geologic map of the Big Delta quadrangle, Alaska: U.S. Geological Survey Open-File Report 78-529-A, scale 1:250,000.

Wilson, F.H., Smith, J.G., and Shew, Nora, 1985, Review of radiometric data from the Yukon Crystalline Terrane, Alaska and Yukon Territory: Canadian Journal of Earth Sciences, v. 22, p. 525-537. 


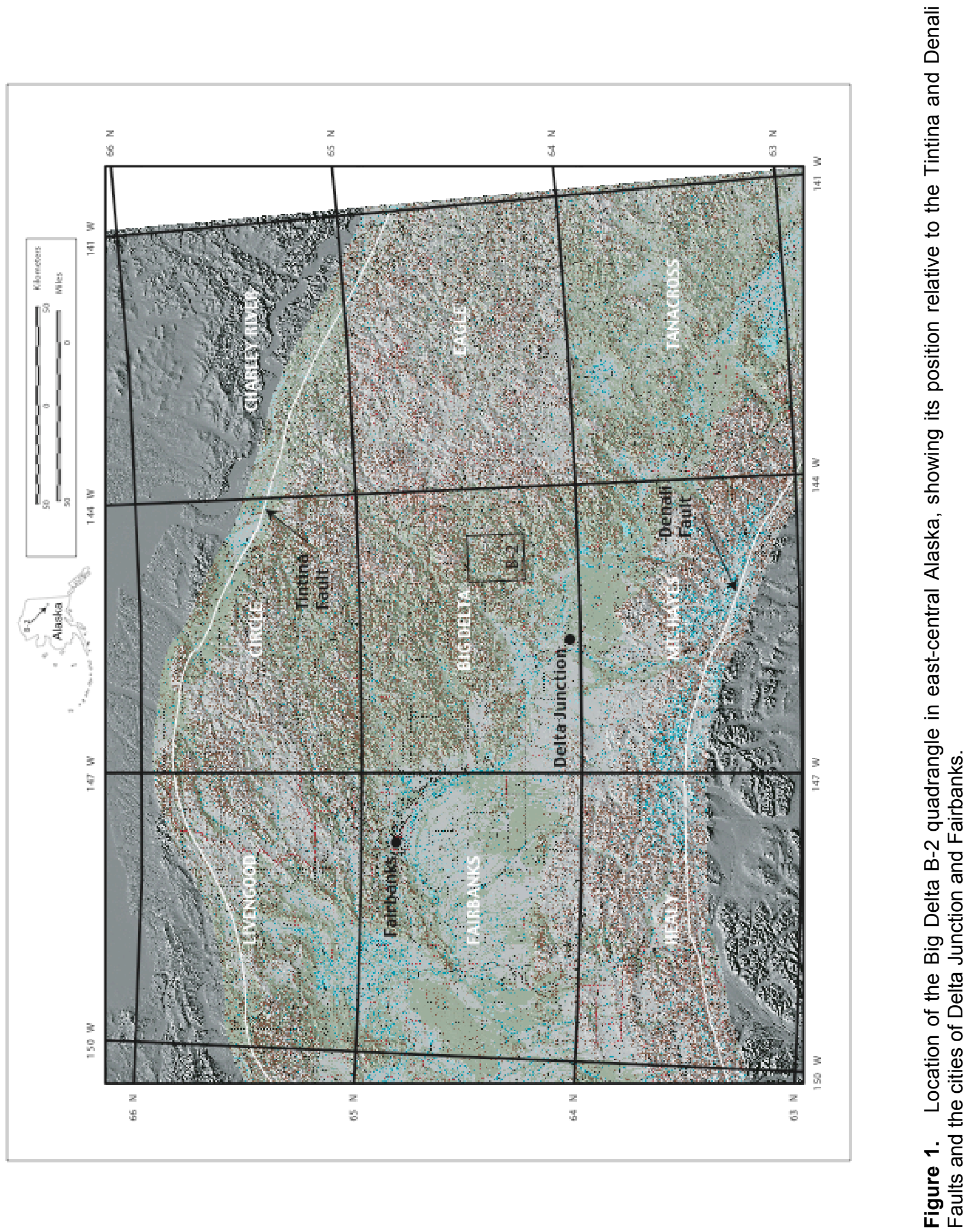




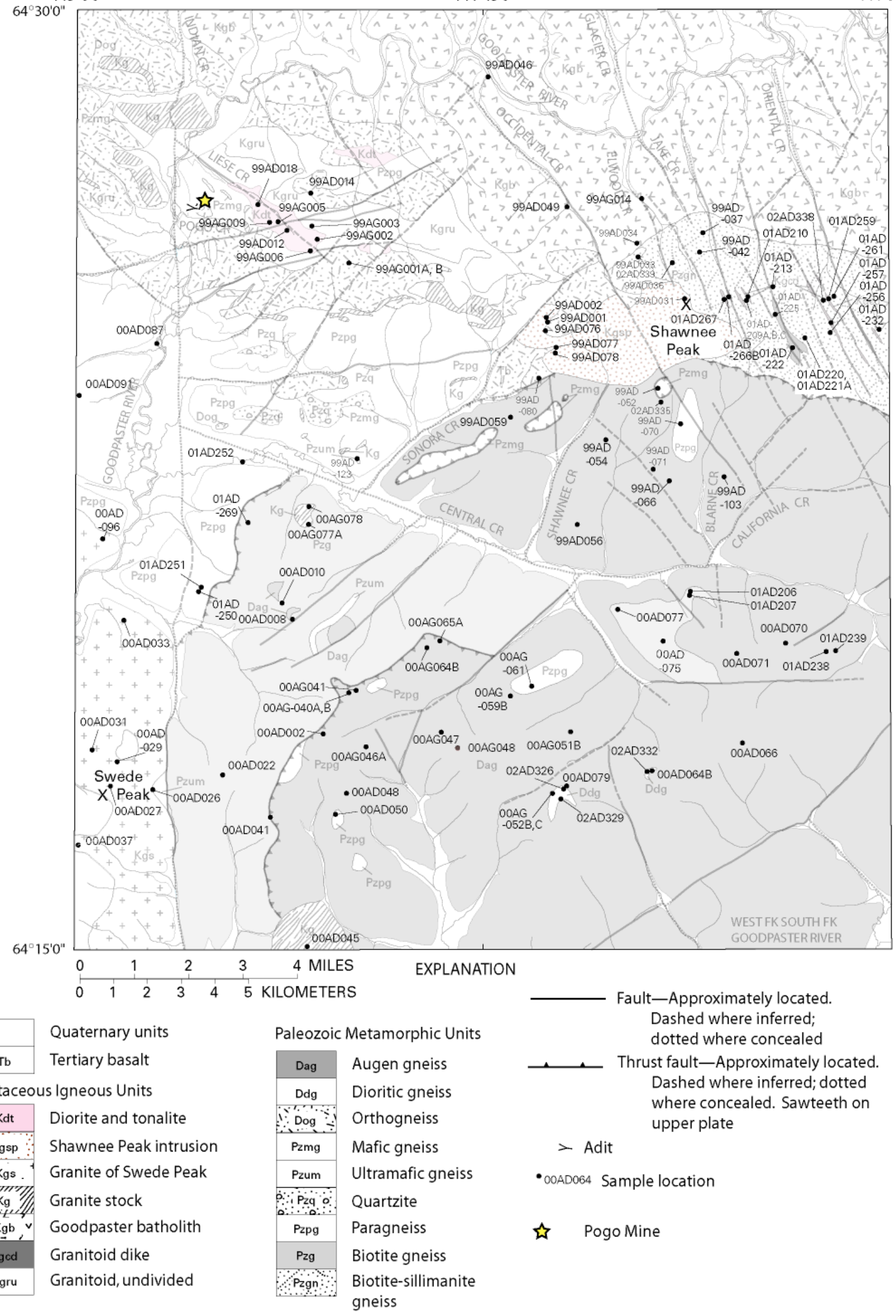

Figure 2. Location of bedrock and quartz vein samples and generalized geologic map of the Big Delta B-2 quadrangle, Alaska. For precise sample site coordinates refer to tables 3, 4, and 5. Modified after Day and others (2003). 


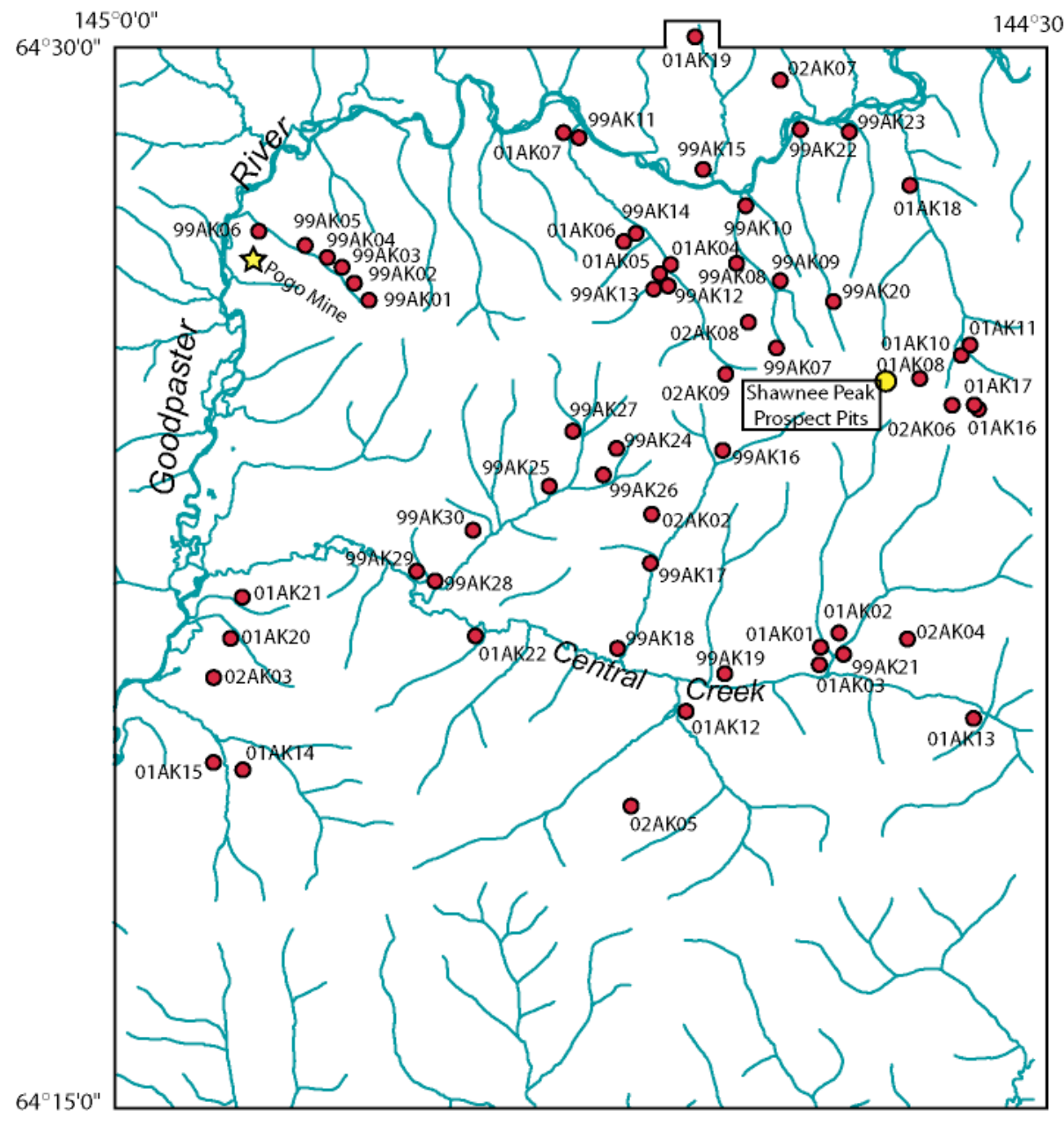

Figure 3. Labeled vegetation and soil sampling sites in the Big Delta B-2 quadrangle, Alaska superimposed on the regional hydrology. For precise site coordinates refer to table 2. 


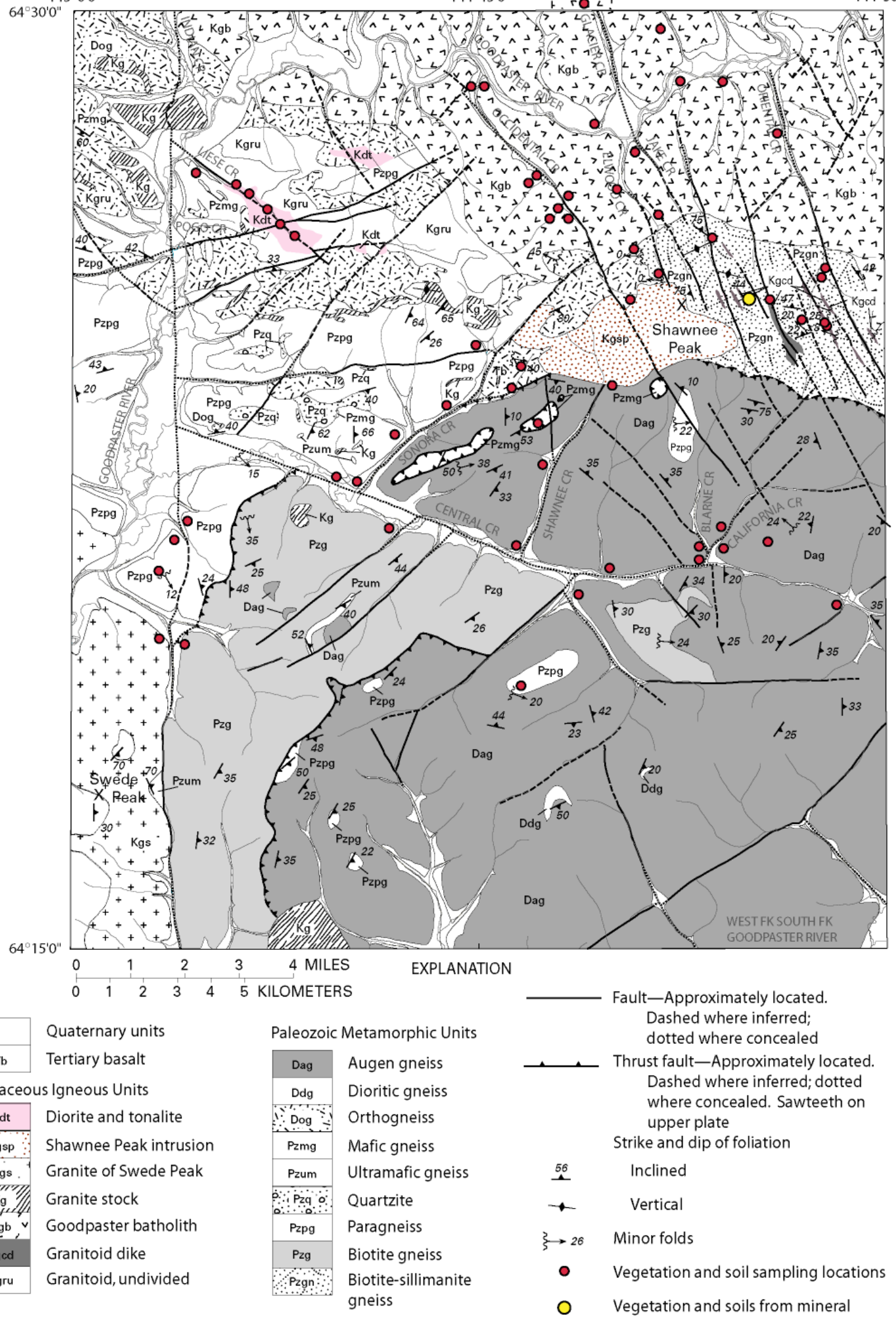

prospecting pits on Shawnee Peak

Figure 4. Generalized geologic map of the Big Delta B-2 quadrangle, Alaska with vegetation and soil sampling locations. For precise site coordinates refer to figure 3 and table 2. Modified after Day and others (2003). 